\title{
Inhibition of DNA Synthesis by Somatostatin in Rat Hepatocytes Stimulated by Hepatocyte Growth Factor or Epidermal Growth Factor
}

\author{
Norihiro Kokudo, mD, Piyush C. Kothary, MS, Frederic E. Eckhauser, MD, Ann Arbor, Michigan, \\ Toshikazu Nakamura, PhD, Fukuoka, Japan, Steven E. Raper, MD, Ann Arbor. Michigan
}

The antiproliferative effects of somatostatin on hepatocytes stimulated by hepatocyte growth factor (HGF) or epidermal growth factor (EGF) were investigated using primary cultures of adult rat hepatocytes. Somatostatin inhibits HGF-induced (at a dose of $10 \mathrm{ng} / \mathrm{mL}$ ) or EGF-induced (at a dose of $100 \mathrm{ng} / \mathrm{mL})^{3} \mathrm{H}$-thymidine incorporation into hepatocytes in a dose-dependent manner $\left(10^{-10}\right.$ to $\left.10^{-8} \mathrm{M}\right)$. This inhibition was confirmed by autoradiography. The effect of somatostatin was nontoxic as judged by preserved albumin synthesis, a marker for differentiated hepatocyte function. In the presence or absence of somatostatin, neither HGF nor EGF significantly altered intracellular cyclic adenosine monophosphate (cAMP). We conclude that somatostatin is a potent inhibitor of HGF- or EGF-induced deoxyribonucleic acid synthesis in adult rat hepatocytes. The mechanism of this inhibition appears to be independent of AMP. The significance of somatostatin in liver regeneration has yet to be assessed.
From the Department of Surgery (NK, PCK, FEE, SER), University of Michigan Medical Center, Ann Arbor, Michigan, and the Department of Biology (TN), Kyushu University, Fukuoka, Japan. This work was supported by National Institutes of Health grant 1 R29 DK4248501 and a Career Development Award from the Society for Surgery of the Alimentary Tract.

Requests for reprints should be addressed to Steven E. Raper, MD, Department of Surgery, 2922H Taubman Health Care Center, 1500 East Medical Center Drive, Ann Arbor, Michigan 48109-0331.

Presented at the 32nd Annual Meeting of the Society for Surgery of the Alimentary Tract, New Orleans, Louisiana, May 20-22, 1991.
7 he liver has a remarkable capacity to regenerate after hepatectomy or injury. In normal rats, resected liver grows rapidly, doubles in size within 48 hours, and resumes its original volume within 7 to 10 days [1]. There have been a variety of investigations on humoral factors that may trigger or promote liver growth. Insulin, glucagon, epidermal growth factor (EGF), norepinephrine, and vasopressin are all known hepatotrophic factors [2]. Recently, hepatocyte growth factor (HGF) has been discovered as a potent liver mitogen and has been postulated to play a major role in liver growth $[3,4]$.

In contrast to uncontrolled or autonomous tumor growth, cellular proliferation associated with liver regeneration is strictly controlled and ceases once the original liver mass is restored. A variety of tissue specific substances that inhibit deoxyribonucleic acid (DNA) synthesis of the liver in vitro [5] or in vivo [G] have been suggested to explain this strict regulation. However, only transforming growth factor $\beta[7,8]$ and heparin-binding growth factor type 1 [9] have been well characterized. Our knowledge of the regulating process of this phenomenon is still incomplete.

Somatostatin is known to inhibit the growth of a number of cell types such as gastrointestinal mucosa [10], exocrine pancreas [11], lymphocytes [12], and some tumors [13]. We have recently shown that somatostatin inhibits DNA synthesis in rat hepatocytes stimulated by insulin or cAMP analogue $[14,15]$ and that the liver takes up intraportally injected somatostatin-14 in an efficient and saturable manner [10]. These findings, taken together with the fact that immunoreactive somatostatin levels measured in the portal vein are 10 times higher than in systemic circulation [17], have led us to hypothesize that somatostatin may play an important role in regulating liver regeneration. In this study, we used primary cultures of adult rat hepatocytes to investigate the effects of somatostatin on DNA synthesis stimulated by HGF or EGF.

\section{MATERIAL AND METHODS}

Materials: Synthetic somatostatin-14 (SS-14), human insulin, and epidermal growth factor fragment [Cys$\left(\mathrm{Acm}{ }^{20,31}\right)$ ]-EGF20-31 (EGF) [18] were purchased from Peninsula Laboratories, Inc. (Belmont, CA). Human recombinant HGF (HGF) [4] was kindly supplied by Dr. Toshikazu Nakamura (Fukuoka, Japan). Collagenase (type I) was obtained from Sigma Chemical Co. (St. Louis, MO). Matrigel and Dispase were obtained from Collaborative Research Inc. (Bedford, MA). All chemicals used for sodium dodecyl polyacrylamide gel electro- 


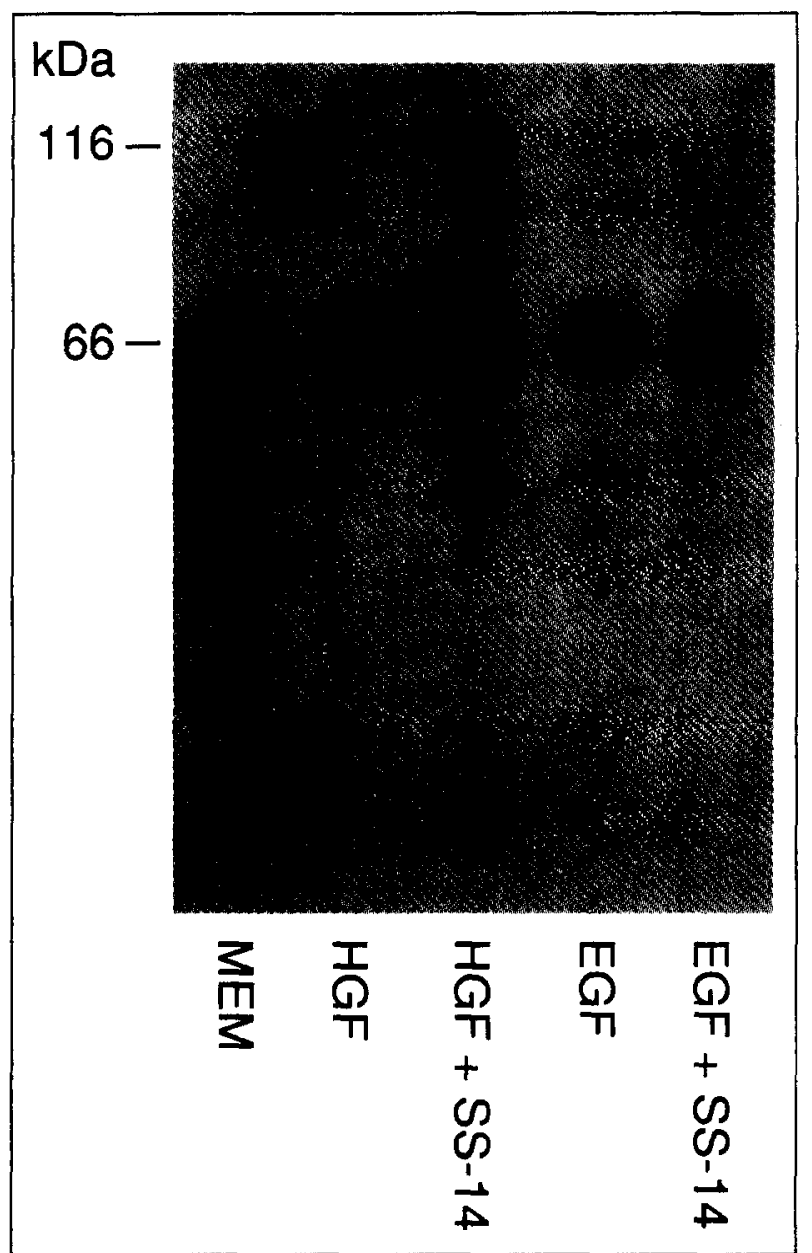

Figure 1. Immunoblot analysis of albumin secreted into the media by rat hepatocytes. The media $(25 \mu \mathrm{L})$ from hepatocyte culture dishes treated with appropriate reagents for 24 hours were subjected to electrophoresis (SDS.PACE) and Immunoblot analysis using antirat albumin antibodies (Organon Teknlka Corp., Westchester, PA) [14,21]. MEM: medla only, HGF: $10 \mathrm{ng} / \mathrm{mL}$, EGF: $100 \mathrm{ng} / \mathrm{mL}$, SS-14: $10^{-8} \mathrm{M}$. The flgure is representative of three independent experiments. ECF = epidermal growth factor; HCF = hepatocyte growth factor; SS-14 = synthetlc somatostatin-14; MEM = minimum essentlal medium; $\mathrm{kDa}=$ kllodaltons.

phoresis and immunoblot analysis were obtained from BioRad (Richmond, CA).

Hepatocyte isolation: The hepatocytes of SpragueDawley male rat ( 250 to $275 \mathrm{~g}$ ) were isolated using a twostep collagenase perfusion technique described previously $[14,15,19]$. Briefly, rat liver was portally perfused for 10 minutes with $\mathrm{Mg}^{2+} / \mathrm{Ca}^{2+}$ free Hank's buffer at $37^{\circ} \mathrm{C}$ followed by 8 to 10 minutes with Eagle's minimum essential medium (MEM) (GIBCO, Grand Island, NY) containing $0.05 \%$ collagenase (type I). The liver was excised and placed in a Petri dish containing fresh MEM with collagenase. The liver capsule was stripped, and cells were released by gentle manipulation. The resulting crude preparation was filtered through $250-\mu \mathrm{m}$ nylon mesh, and the collagenase was inactivated with $0.5 \mathrm{~mL}$ of fetal calf serum. Centrifugal separation was employed to minimize contamination by nonparenchymal cells. Cell viability was tested by trypan blue exclusion (greater than

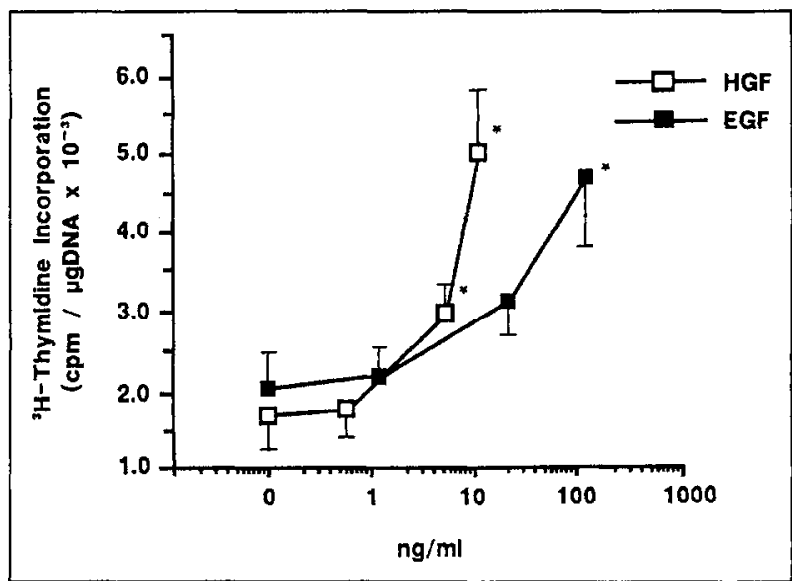

Figure 2. Dose-dependent stimulation of ${ }^{3} \mathrm{H}$-thymidine incorporathon by HGF and EGF. Freshly isolated hepatocytes were plated as described in text. After a 24hour attachment perlod, medla was changed, and hepatocyte growth factor (HCF) $(0.5$ to $10 \mathrm{ng} / \mathrm{mL}$ ) or epldermal growth factor (EGF) (1 to $100 \mathrm{ng} / \mathrm{mL}$ ) was added. ${ }^{3} \mathrm{H} /$ thymidine incorporation into deoxyribonucleic acid (DNA) was measured after 18-hour exposure to ${ }^{3} \mathrm{H}$-thymidine $(2 \mu \mathrm{Cl} / \mathrm{dish})$. Points indicate the means of 6 to 10 dishes from three different experiments; bars, SEM. "p $<0.06$ versus control $(0 \mathrm{ng} / \mathrm{mL}$ of HCF or EGF).

90\%). The hepatocytes were plated at a cell density of $10^{5}$ per 16-mm tissue culture dish coated with $250 \mu \mathrm{L}$ (1:3 volume for volume) of Matrigel (laminin, heparan sulfate, type IV collagen) [20]. The medium was supplemented with insulin $(100 \mathrm{ng} / \mathrm{mL})$. To check the purity of the isolated hepatocytes and to exclude the possibility of toxicity by SS-14, we carried out an immunoblot analysis [21] of the media from hepatocyte culture dishes treated with HGF or EGF in the presence or absence of SS-14. The immunoblot analysis of the media using antirat albumin antibodies (Organon Teknica Corp., Westchester, PA) showed a single band of albumin, the molecular weight of which corresponded to chromatographically purified rat albumin (Organon Teknica Corp.) (Figure 1). These findings confirm that cultured hepatocytes in the present study were pure and functional.

Estimation of DNA synthesis: DNA synthesis was estimated by the rate of ${ }^{3} \mathrm{H}$-thymidine incorporation into DNA [22] and by autoradiographic measurement of the number of labeled nuclei.

After a 24-hour attachment period, media was changed and the appropriate reagents were added. The cell culture was maintained up to 3 days, and the media were changed daily. ${ }^{3} \mathrm{H}$-thymidine $(2 \mu \mathrm{Ci} /$ dish $)$ was added 18 hours before harvest, which was performed using Dispase (a neutral protease produced by Bacillus polymyxa) [23] for 2 hours at $37^{\circ} \mathrm{C}$. Half of the harvested cells were processed for counting, and the other half were used to determine DNA content. The former half was filtered onto GF/C Whatman filters and rinsed with 1 $\mathrm{mL}$ of ice-cold $15 \%$ trichloroacetic acid (TCA) twice and with $70 \%$ ethanol once. Filters were dried and placed in $10 \mathrm{~mL}$ of scintillation cocktail (EcoLite, ICN Biochemicals, Inc., Irvine, CA) and were counted in a scintillation 


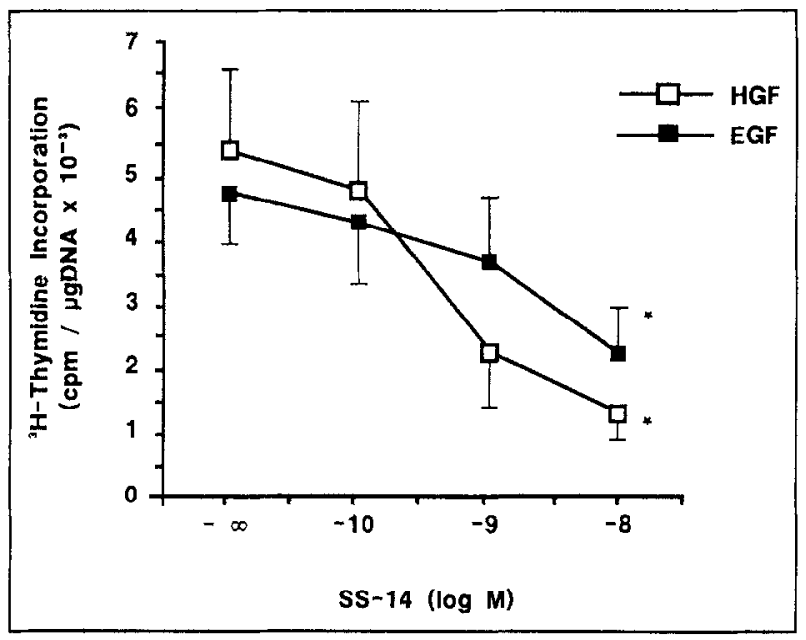

Figure 3. Effect of synthetic somatostatin-14 (SS-14) on deoxyrbonucleic acid (DNA) synthesls stimulated by hepatocyte growth factor (HCF) or epldermal growth factor (ECF). Hepatocytes were treated with HCF $(10 \mathrm{ng} / \mathrm{mL})$ or wh ECF $(100 \mathrm{ng} / \mathrm{mL})$ in the presence or absence of SS $14\left(10^{-10}\right.$ to $\left.10^{-8} \mathrm{M}\right)$. Methods for determining ${ }^{3}$ Ht thymidine incorporation were as for Figure 2. Points indlcate the means from 6 to 8 dishes from two different experiments; bers, SEM. " $p<0.05$ versus HCF- or EGF-stimulated ${ }^{3} H$-thymidine incorporation in absence of SS-14.

counter (Beckman LS 6,000LL, Beckman Instruments, Inc., Fullerton, CA). A modified diphenylamine reaction for desoxypentose was performed to measure DNA content [24]. ${ }^{3} \mathrm{H}$-thymidine incorporation was expressed as counts per minute (cpm)/ $\mu \mathrm{g}$ DNA.

The labeling index, i.e., the percentage of total nuclei labeled with ${ }^{3} \mathrm{H}$-thymidine, was measured as follows. After 18 -hour exposure to ${ }^{3} \mathrm{H}$-thymidine $(2 \mu \mathrm{Ci} / \mathrm{dish})$, hepatocytes were washed twice with cold phosphate-buffered saline and fixed in $4 \%$ paraformaldehyde for 10 minutes, coated with Kodak NTB-3 emulsion (Eastman Kodak, Rochester, NY) and exposed for 10 days before development in Kodak Dektol. The percentage of morphologically defined hepatocytes with labeled nuclei was determined by phase contrast microscopy.

Cyclic AMP assay: Freshly isolated hepatocytes $\left(10^{5} / \mathrm{mL}\right)$ were incubated in glass tubes with the appropriate reagents for 5 minutes. Following incubation, the test tubes were placed in an ice-water bath for $10 \mathrm{~min}$ utes, vortexed gently, and centrifuged at $1,800 \mathrm{~g}$ for 10 minutes at $4^{\circ} \mathrm{C}$. The pellet was deproteinized with $15 \%$ TCA, ether extracted, and lyophilized. Cyclic AMP levels were measured by a competitive protein binding assay using an Amersham kit (Amersham Life Science Products, Arlington Heights, IL).

Statistical analysis: All values shown represent the mean \pm standard error of the mean (SEM). Wilcoxon signed rank test was used for comparing group means. The level of significance was established at $\mathrm{p}<0.05$.

\section{RESULTS}

Effect of HGF and EGF on hepatocyte DNA synthesis: HGF and EGF stimulated ${ }^{3} \mathrm{H}$-thymidine incorpo-

\begin{tabular}{|c|c|}
\hline \multicolumn{2}{|c|}{$\begin{array}{l}\text { TABLE I } \\
\text { Effect of SS-14 on HGF- and EGF-Stimulated } \\
\text { Labeling Index }\end{array}$} \\
\hline Reagents & Labeling Index (\%)* \\
\hline $\begin{array}{l}\text { Control } \\
\text { HGF }(10 \mathrm{ng} / \mathrm{mL}) \\
\quad+\text { SS-14 }(10 \mathrm{nM}) \\
\text { EGF }(100 \mathrm{ng} / \mathrm{mL}) \\
\quad+S S-14\end{array}$ & $\begin{array}{l}26.0 \pm 3.2 \\
50.5 \pm 5.1^{\dagger} \\
22.2 \pm 3.8^{\ddagger} \\
49.0 \pm 5.3^{\dagger} \\
24.8 \pm 4.7^{\ddagger}\end{array}$ \\
\hline \multicolumn{2}{|c|}{$\begin{array}{l}\text { HGF = hepatocyte growth factor; EGF = epidermal growth factor; SS-14 = } \\
\text { synthetic somatostath-14. } \\
\text { "The labeling index, i.e., the percentage of nuclei labeled with 3H-thymidine, } \\
\text { was measured as described in "Materials and Methods." Data are the mean } \\
\text { SEM from } 9 \text { to } 12 \text { determinations from two different experiments. } \\
t_{p}<0.05 \text { versus control. } \\
{ }_{f}<<0.05 \text { versus HGF-or EGF-stimulated labeling index. }\end{array}$} \\
\hline
\end{tabular}

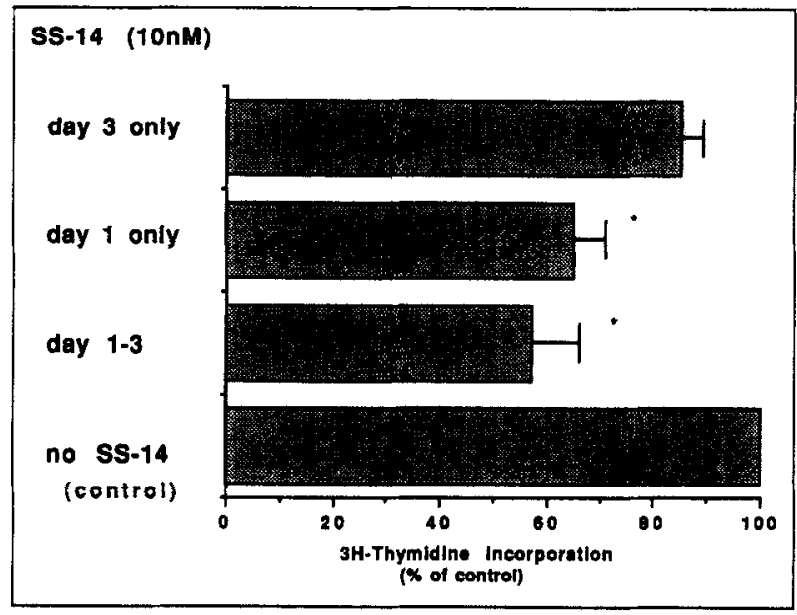

Figure 4. Effect of timing of synthetic somatostatin-14 (SS-14) exposure on deoxyrlbonucleic acid (DNA) synthesis. Hepatocyte cultures were maintained for 3 days in the presence of epldermal growth factor (ECF) $(100 \mathrm{ng} / \mathrm{mL})$, and $3 \mathrm{H}$-thymidine incorporation (cpm/ $\mu \mathrm{g}$ DNA) during the last 18 hours was measured. The cells were exposed to SS-14 $\left(10^{-8} \mathrm{M}\right)$ at various intervals as indicated on the ordinate. Values are expressed as \% of control (no SS14). Columns indicate the means from $B$ dishes from two different experiments; bars, SEM. " $p<0.05$ versus control.

ration into hepatocytes in a dose-dependent manner $(0.5$ to $10 \mathrm{ng} / \mathrm{mL}$ and 1 to $100 \mathrm{ng} / \mathrm{mL}$, respectively, Figure 2). Of the tested doses, $10 \mathrm{ng} / \mathrm{mL}$ of $\mathrm{HGF}$ and $100 \mathrm{ng} / \mathrm{mL}$ of EGF were most effective, and these concentrations were used thereafter.

Effect of SS-14 on DNA synthesis stimulated by HGF and EGF: Increasing concentrations of SS-14 $\left(10^{-10} \mathrm{M}\right.$ to $\left.10^{-8} \mathrm{M}\right)$ progressively inhibited hepatocyte DNA synthesis stimulated by HGF and EGF (Figure 3). Since the optimal effect of SS-14 was reached at $10^{-8} \mathrm{M}$, this concentration was used for all remaining experiments. No significant morphological changes in hepatocytes exposed to $10^{-8} \mathrm{M}$ of SS-14 were observed. Further, SS-14 significantly decreased the labeling index of the hepatocytes stimulated by HGF or EGF (Table I). 
This also confirms the inhibitory effect of SS-14 on DNA synthesis stimulated by HGF or by EGF.

Effect of timing of SS-14 exposure on DNA synthesis: To determine whether a critical period exists during which hepatocytes are sensitive to the antiproliferative effect of SS-14, hepatocytes stimulated with EGF were treated with SS-14 $\left(10^{-8} \mathrm{M}\right)$ at different intervals. In these studies (Figure 4), hepatocyte cultures were maintained for 3 days after attachment, and ${ }^{3} \mathrm{H}$-thymidine incorporation during the last 18 hours was measured. The cells were exposed to SS-14 at various intervals as indicated on the ordinate. Exposure of cells to SS-14 between days 1 and 3 produced the highest reduction $(57 \% \pm 9 \%$ of control, $p<0.05)$ in DNA synthesis. Removal of SS-14 after day 1 also significantly inhibited DNA synthesis $(65 \% \pm 6 \%, p<0.05)$. Addition of SS-14 on day 3 did not significantly inhibit EGF-stimulated ${ }^{3} \mathrm{H}$ thymidine incorporation.

Intracellular cAMP: The effects of HGF ( 10 $\mathrm{ng} / \mathrm{mL})$ and EGF (100 $\mathrm{ng} / \mathrm{mL})$ on intracellular cAMP levels in the presence or absence of SS-14 were determined in freshly isolated hepatocytes. Five minutes after the addition of HGF or EGF, there was no significant change in intracellular cAMP $(2.04 \pm 0.52 \mathrm{pmol} /$ tube and $2.76 \pm 0.48 \mathrm{pmol} /$ tube, respectively; $\mathrm{n}=5$ ) compared with control levels $(2.29 \pm 0.49 \mathrm{pmol} /$ tube, $\mathrm{n}=9)$. In the presence of SS-14 $\left(10^{-8} \mathrm{M}\right)$, cAMP levels deviated slightly (HGF + SS-14, $2.10 \pm 0.58 \mathrm{pmol} /$ tube; EGF + SS-14, $2.35 \pm 0.19 \mathrm{pmol} /$ tube; $n=5)$, but these changes were not statistically significant.

\section{COMMENTS}

The present study shows that SS-14 inhibits HGF- or EGF-induced DNA synthesis in adult rat hepatocytes in a dose-dependent manner. This inhibition was apparently nontoxic as evidenced by the observation that albumin synthesis, a marker for differentiated hepatocyte function was maintained in cells treated with SS-14 (Figure 1) [14]. SS-14 exerted its inhibitory action when present even only on day 1 of a 3-day culture but had no significant effect when added on day 3 only. This suggests that somatostatin inhibits the early proliferative response of hepatocytes, and this is supported by the observation that somatostatin blocked EGF-induced centrosomal separation, a biological marker of early Gl phase in gerbil fibroma and HeLa cells [13].

The mechanism by which somatostatin inhibits cell proliferation is unknown. In previous studies using a number of cell types including hepatocytes, somatostatin has been shown to inhibit various cellular events by attenuating the production of cellular CAMP [25]. We have shown in isolated hepatocytes that somatostatin exerts at least part of its antiproliferative effects via the adenylate cyclase system $[14,15]$. Tsuzaki et al $[26]$ reported that somatostatin inhibits DNA synthesis in FRTL5 line of rat thyroid follicular cells stimulated by thyroid-stimulating hormone (TSH), which is known to act via the adenylate cyclase system. EGF has not been shown to alter cellular CAMP in hepatocytes [27]. After binding to its cell surface receptor, EGF rapidly activates the receptor's intrinsic tyrosine kinase. Although the kinase activity is assumed to be important in signal generation, the mechanism coupling this early response and delayed responses such as DNA synthesis is unknown [28]. Human lung fibroblast-derived mitogen (a variant of HGF) has recently shown to induce rapid tyrosine phosphorylation in human mammary epithelial cells [29]. However, little is known about signalling mechanisms for HGF action. Since there were no alterations in intracellular cAMP levels as shown in this study, it appears that the inhibitory action of somatostatin on DNA synthesis stimulated by HGF or EGF is mediated via cAMP independent mechanism. Further study of other signal transduction systems may yield more information about mechanisms of hepatocyte growth regulation.

The significance of somatostatin for growth control in vivo has yet to be assessed. Somatostatin is widely distributed in the gastrointestinal system and is produced in the pancreas as well as the gut [30]. Patel et al [17] have reported that immunoreactive somatostatin levels identified in the portal vein are more than 10 times higher than those identified in the systemic circulation. Although the predominant effect of somatostatin is presumed to be paracrine, this peptide may directly influence the liver by way of the portal circulation.

We conclude that somatostatin inhibits the early phase of hepatocyte proliferation stimulated by liver mitogens HGF and EGF. Somatostatin may be important in the modulation of normal liver growth and repair, perhaps to prevent uncontrolled hepatocyte proliferation.

\section{RFFERENCES}

1. Higgins GM, Anderson RM. Experimental pathology of the liver. I. Restoration of the liver of the white rat following partial surgical removal. Arch Pathol 1931; 12: 186-202.

2. Fausto N. Hepatic regeneration. In: Zakim D, Boyer TD, editors. Hepatology: a textbook of liver disease, Vol 1. Philadelphia: WB Saunders, 1990: 49-65.

3. Nakamura T, Teramoto $H$, Ichihara A. Purification and characterization of a growth factor from rat platelets for mature parenchymal hepatocytes in primary cultures. Proc Natl Acad Sci USA 1986; 83: 6489-93.

4. Nakamura $T$, Nishizawa $T$, Hagiya $M$, et al. Molecular cloning and expression of human hepatocyte growth factor. Nature 1989; 342: $440-3$

5. Otsuka $H$, Terayama $H$. Inhibition of DNA synthesis in ascites hepatoma cells by normal liver extract. Biochim Biophys Acta 1966; 123: 274-85.

6. Makowka L, Falk RE, Falk JA, et al. The effect of liver cytosol on hepatic regeneration and tumor growth. Cancer 1983; 51: 2181-90.

7. Carr BI, Hayashi I, Braum EL, Moses HL. Inhibition of DNA synthesis in rat hepatocytes by piatelet-derived type $\beta$ transforming growth factor. Cancer Res 1986; 46: 2330-4.

8. Russell WE, Coffey RJ, Ouellette AJ, Moses HL. Type $\beta$ transforming growth factor reversibly inhibits the early proliferative response to partial hepatectomy in the rat. Proc Natl Acad Sci USA 1988; 85: 5126-30.

9. Kan M, Huang J, Mansson P-E, Yasumitsu H, Carr B, McKeehan WL. Heparin-binding growth factor type 1 (acidic fibroblast growth factor): a potential biphasic autocrine and paracrine regulator of hepatocyte regeneration. Proc Natl Acad Sci USA 1989; 86: 7432-6. 
10. Lehy T, Dubrasquet $M$, Bonfils $S$. Effect of somatostatin on normal and gastric-stimulated cell proliferation in the gastric and intestinal mucosae of the rat. Digestion 1979; 19: 99-109.

11. Morriset J. Somatostatin: a potential antigrowth factor for the exocrine pancreas. Regul Pept 1984; 10: 11-22.

12. Pawlikowski $M$, Stepien $H$, Kunert-Radek J, et al. Immunomodulatory action of somatostatin. Ann NY Acad Sci 1987; 496: 233-9.

13. Mascardo RN, Sherline P. Somatostatin inhibits rapid centrosomal separation and cell proliferation induced by epidermal growth factor. Endocrinology 1982; 111: 1394-6.

14. Raper SE, Kothary PC, Kokudo N. Somatostatin-14 blocks the hepatotrophic effects of insulin in the rat. J Surg Res 1991; 50: 386-90.

15. Kokudo N, Kothary PC, Eckhauser FE, Raper SE. Inhibitory effects of somatostatin on hepatocyte proliferation are mediated by cyclic AMP. J Surg Res 1991; 51: 113-8.

16. Raper SE, Kothary PC, Kokudo N, DelValle J. The liver plays an important role in the regulation of somatostatin-14 metabolism in the rat. Am J Surg 1991; 161: 184-9.

17. Patel YC, Wheatley T, Fitz-Patrick D, Brock G. A sensitive radioimmunoassay for immunoreactive somatostatin in extracted plasma: measurement and characterization of portal and peripheral plasma in the rat. Endocrinology 1980; 107: 306-13.

18. Komoriya A, Hortsch M, Meyers C, Smith M, Kanety H, Schlessinger J. Biologically active synthetic fragments of epidermal growth factor: localization of a major receptor-binding region. Proc Natl Acad Sci USA 1984; 81: 1351-5.

19. Seglen PO. Preparation of isolated rat liver cells. Methods Cell Biol 1976; 13: 29-83.

20. Bissell DM, Arenson DM, Maher JJ, et al. Support of cultured hepatocytes by a laminin-rich gel. J Clin Invest 1987; 79: 801-12. 21. Renat J, Reiser J, Stark GR. Transfer of proteins from gels to diazobenzyloxymethyl-paper and detection with antisera: a method for studying antibody specificity and antigen structure. Proc Natl Acad Sci USA 1979; 76: 3116-20.

22. McGowan JA, Strain AJ, Bucher NL. DNA synthesis in primary cultures of adult rat hepatocytes in a defined medium: effect of epidermal growth factor, insulin, glucagon, and cyclicAMP. J Cell Physiol 1981; 108: 353-63.

23. Matsumura T, Yamanaka T, Hashizume S, Irie Y, Nitta $K$ Tissue dispersion, cell harvest and fluid suspension culture by the use of bacterial neutral protease. Jpn J Exp Med 1975; 45: 377-82. 24. Volkin $E$, Cohn WE. Estimation of nucleic acids. Methods Biochem Anal 1956; 1: 287-305.

25. Koch BD, Dorflinger LJ, Schonbrunn A. Pertussis toxin blocks both cyclic AMP-mediated and cyclic AMP-independent actions of somatostatin. J Biol Chem 1985; 260: 13138-45.
26. Tsuzaki S, Moses AC. Somatostatin inhibits deoxyribonucleic acid synthesis induced by both thyrotropin and insulin-like growth factor-I in FRTL5 cells. Endocrinology 1990; 126: 3131-8.

27. Choudhury MH, Agius L. Epidermal growth factor counteracts the glycogenic effect of insulin in parenchymal hepatocyte cultures. Biochem J 1987; 247: 307-14.

28. McCune BK, Earp HS. The epidermal growth factor receptor tyrosine kinase in liver epithelial cells. J Biol Chem 1989; 264 15501-7.

29. Rubin JS, Chan AM-L, Bottalo DP, et al. A broad-spectrum human lung fibroblast-derived mitogen is a variant of hepatocyte growth factor. Proc Natl Acad Sci USA 1991; 88: 415-19.

30. Reichlin S. Somatostatin. N Engl J Med 1983; 309: 1495-501.

\section{DISCUSSION}

William C. Meyers (Durham, NC): We've just completed a similar experiment and found similar results. Sandostatin (Sandoz, Ltd., Basle, Switzerland) does inhibit regeneration in the $70 \%$ hepatectomy model of $\mathrm{Mi}$ chalopoulos (Cancer Res 1989; 49: 3314-20), and also BRDU (bromodeoxyuridine) incorporation. When the administration of Sandostatin is stopped, regeneration goes back to the previous curve. Have you had any experience with an in vivo model to confirm your results?

David Allison (Baltimore, MD): You've shown that thymidine incorporation has been altered. As you know, thymidine incorporation can be influenced by the pool levels of thymidine in a cell. Do you have any cytophotometric evidence to show that these differences in thymidine incorporation actually relate to differences in DNA synthesis?

Norihiro Kokudo (closing): We have not done any experiments using Sandostatin (octreotide) in vivo. Goldman (Surg Forum 1978: 29; 402-4) reported that intravenous infusion of somatostatin inhibited liver regeneration after partial hepatectomy in rats. Since somatostatin inhibits insulin and glucagon in vivo, which are known hepatotrophic factors, it is very difficult to prove whether there is a direct inhibitory effect of somatostatin or not.

Dr. Allison, the histologic evidence we have relates to the significant changes seen in the nuclear labeling index (Table I). The predominance of silver grains over the nuclei precludes the presence of intracellular cytoplasmic pools of tritiated thymidine as a source of error. 